\title{
The Impact of Employee Loyalty on the Success of Commercial Organizations: A Case Study on the Dealerships of Heavy Equipment in Iran
}

\author{
Shahram Nasiri ${ }^{1, ~}$, Reza Najafbagy ${ }^{2}$, Amir Ashkan Nasiripour $^{3}$ \\ ${ }^{1}$ Department of Business management, Science and Research Branch, Islamic Azad University, Tehran, Iran \\ ${ }^{2}$ Department of Public management, Science and Research Branch, Islamic Azad University, Tehran, Iran \\ ${ }^{3}$ Department of Health Services management, Science and Research Branch, Islamic Azad University, Tehran, Iran
}

Email address:

shahraamn@gmail.com (S. Nasiri)

\section{To cite this article:}

Shahram Nasiri, Reza Najafbagy, Amir Ashkan Nasiripour. The Impact of Employee Loyalty on the Success of Commercial Organizations: A Case Study on the Dealerships of Heavy Equipment in Iran. Journal of Human Resource Management. Vol. 3, No. 3, 2015 , pp. $27-32$. doi: $10.11648 /$ j.jhrm.20150303.12

\begin{abstract}
Nowadays, regardless of what industry they are in, all organizations and managers are vigorously pursuing success, and the basic touchstone to achieve success in any organization, particularly a commercial organization, is having satisfied and loyal customers. Nonetheless, this ideal condition would never be met unless the organization enjoys a team of loyal staff. That is to say keeping satisfied and loyal customers will only be feasible in case of having satisfied and loyal staff, seeing that it is the latter who play the key role in conferring value to the organization and earning the loyalty and consent of the former. This study aimed at evaluating the role of employee loyalty in the success of commercial organizations in the field of heavy equipment dealerships. To this end, data was collected through library resources as well as a survey. The sample was comprised of 280 employees of heavy equipment dealerships and 280 customers who had referred to these dealers. This study involved 7 hypotheses, which were analyzed and checked through Pearson Correlation Coefficient and Regression. The findings show that organizational successful directly affected by loyalty of staff. Besides, positive correlations were reported between employee loyalty and services quality, between services quality and customer satisfaction and loyalty as well as between customer satisfaction and loyalty and success of organizations.
\end{abstract}

Keywords: Customer Loyalty, Employee Loyalty, Organizational Success, Service Quality

\section{Introduction}

The economic performance of firms, whatever their sector of activity, is becoming ever more dependent on the participation, commitment, and more generally, loyalty of their employees (Boltanski \& Chiapello, 2001). In the 1990s, Robert Kaplan and David Norton stated that Learning and Growth perspective of the employees is the foundation of a Balanced Scorecard system and the main factor in achieving the financial goals set by an organization (Kaplan \& Norton, 2008). Therefore, it is necessary for every organization to pay ample attention to the loyalty of their employees in order to promote their domestic processes and to prevent the waste of resources caused by the employees' leaving. These days Companies deploy diverse marketing strategies, both internally and externally, to improve customer satisfaction (Spinelli \& Canavos, 2000). Meanwhile, theoretical discussions as well as anecdotal illustrations have investigated how employee loyalty could, in turn, result in excellent customer service and customer loyalty, and hence, ensure the long-term profitability and success of an organization (Ineson, Benke, \& Laszlo, 2013). Organizational loyalty could be defined as the feeling of belonging to a certain organization, in a way that one would be eager to preserve its membership and connection with that organization. That is to say organizational loyalty involves the feeling of dependence, strong desire for membership, tendency to share the duties, feeling of trust, voluntary alignment, and tendency to abide by the rules and regulations of an organization (Adler \& Adler, 1988). Experimental studies highlight that keeping satisfied and loyal customers is infeasible without having a team of loyal staff. Based on previous studies, employees' leaving is influenced by a number of individual, organizational, and environmental 
factors, one very important of which is employee's occupational attitude. Lack of satisfaction, absence of sense of belonging, and lack of loyalty to the organization among the staff could lead to delay, mental or physical absence, and finally leaving the organization. Needless to say is that not only does the leaving of the old-timer employees impose various costs to the organization, but it also negatively impacts the spirit and mood of newly-joined members of the staff (Pourezat, Ehsanimoghadam, Yazdani, \& Faez, 2013). One of the most important measures that managers must take regarding the organizational behavior is to encourage their employees to feel more committed to their organization and their employers. This way, they can guarantee their existence in the arena of international competition (Robbins, 2012). These days, the grave challenge that organizations are faced with is capability of offering services of excellent quality, and keeping their customers satisfied. In an organizational system, customer satisfaction in influenced by the domestic interactions between the customers and the employees. On the other hand, employee satisfaction is influenced by their perception of their occupation and the organization where they work (Guzman, Rodriguez, \& Manautou). In developed countries, production and output by the employees is one of the features of successful companies, in a way that these companies deem their employees as their partners in their general organizational doctrine. Respect, prestige, and value that is conferred to individuals is a prominent feature in a company. Such behavioral approach leads the employees to feel they are members of a family, and brings them close. Mottos such as "let employees stand out", "See to it that the novel ideas of employees are put into practice", and "Treat the employees like VIPs" are parts of the managers' doctrine in these companies (Najafbagy, 2010).

Field observations have it that some employees of the commercial companies, heavy equipment companies included, start a new career in the rival companies after leaving their former organization. After being employed in the rival company, these employees use their connections with the customers of the ex-organization, and convince them purchase their products and services from the rival company where they are currently working. There is no denying that this issue could impose serious financial and non-financial costs to the ex-organization. Targeting such issues, this study aimed at investigating the impact of employee loyalty on the success of commercial organizations, in the particular field of heavy equipment dealers.

\section{Literature Review and Conceptual Model}

\subsection{Literature Review}

The ancient Chinese built the Great Wall in order to protect themselves against their enemies' attacks; yet in the first 100 years of the construction, their enemies managed to attack them three times and break out a war. The enemies did not climb the wall nor did they tear it down; they bribed the gate guards and passed through them. The Chinese made serious attempt to construct a blocking wall, but they did little to train faithful and conscientious guards. This vividly demonstrates the grave role of human resources in any organizational system (Saboori, 2014). Although employee loyalty is an extensively-researched area, the diversity of the economic, geographical and social contexts around us always raises the need for further investigation (Ineson, Benke, \& Laszlo, 2013). Many studies on loyalty in economics and management science have been based upon the analytical framework proposed by Hirschman (1970), and have interpreted it either as an attitude that inspires expression (voice) and discourages departure (exit) from the organization, or as an alternative form of behavior to both voice and exit (Guillon \& Cezanne, 2014). In a study that probes the financial outcomes of employee turnover, Hinkin and Tracey (2000) proposed the five cost categories: separation costs, recruitment costs, selection costs, hiring costs, and loss of productivity costs. They also developed a piece of computer software based on these five categories to ease the labor turnover cost calculations. Their case study revealed unexpectedly high costs related to labor turnover and emphasized the duty of managers and human resources (HR) authorities in retaining staff with practices beyond financial benefits (Ineson, Benke, \& Laszlo, 2013). The studies conducted by Graham (1996) and Hizer (1998) indicated that organizations' efforts in studying the relationship between employee satisfaction, customer satisfaction, efficiency, and financial performance revealed the following points to them:

- Grief-stricken employees have low efficiency and high absence records.

- Satisfied employees are efficient, innovative, and loyal

- An increase in job satisfaction would cheer up the employees, and lead to an increase in efficiency.

- Employee satisfaction leads to customer loyalty (Graham, 1996) (Davidhizar \& Shearer, 1998).

In another study, Gronholdt and Martensen probed the relationship between employee loyalty, customer loyalty, and profitability. The results indicated that employee loyalty and customer loyalty were positively correlation, and so were customer loyalty and profitability. However, there is still room for a lot of research and investigation into loyalty and other traits of employees (Gronholdt \& Martensen, 2001).

\subsection{Conceptual Model and Research Hypotheses}

Hypotheses 1: Employee loyalty has a positive influence on service quality.

Loyal employees who are satisfied with their job show their loyalty to their organization by their hard work, and their commitment to offering high-quality services to their customers. Loveman (1998) asserted that employee loyalty was positively correlated with the quality of service (Yee, Yeung, \& EdwinCheng, 2010).

Hypotheses 2: Service quality has a positive influence on customer satisfaction.

Yi (1990) proposed that service quality is one of the main 
determinants of customer satisfaction (Yee, Yeung, \& EdwinCheng, 2010). The conceptualization of the S-PC indicates that external service value (i.e. value of the services perceived by customers) is directly linked with customer satisfaction (Heskett, Jones, Loveman, Earl Sasser, \& Schlesinger, 1994).

Hypotheses 3: Service quality has a positive influence on customer loyalty.

Hypotheses 4: Customer satisfaction has a positive influence on customer loyalty.

In this regard, Simon, a theoretician of management science, proposed when an organization succeeds in attracting a new customer, customer satisfaction would be the initial point of a long-term relationship between the customer and the organization (Kavoosi \& Saghaee, 2010). It should always be noted that the sole means of establishing loyalty in customers and keeping them regular customers of the organization is to meet their needs, supply their demands, fulfill their expectations, and in one word, keep them satisfied. In addition, the correlation between customer satisfaction and customer loyalty is largely influenced by the market conditions. That is to say under the condition of exclusiveness and uniqueness of the supplier, absence of rival suppliers, or extremely high costs of shifting to new suppliers, the supplier has no way out except for staying loyal to the first organization. This type of loyalty is commonly referred to as false loyalty. In other words, in case the conditions of exclusiveness gradually fade away, and the market moves toward competitive conditions, customer loyalty to exclusive suppliers would decrease (Dadkhah, 2010).

Hypotheses 5: Customer satisfaction has a positive influence on success in commercial organizations.

Other than leading to customer loyalty, customer satisfaction could give rise to other benefits. For instance, it could promote the non-financial aspects of an organization. Satisfied customers would make oral advertisement for the products and services of that organization. This matter could not only reduce the advertisement costs of the company, also increase the value and the popularity of its brand. Satisfied customers offer a more complete feedback concerning the products and services of a company, and they are hence of great value to the companies.

Hypotheses 6: Customer loyalty has a positive influence on success in commercial organizations.

Other than encouraging other individuals to purchase from the organization, loyal customers make regular purchase from the company themselves. These two matters would have a strong positive impact on helping the company reach its financial prospects and to have a larger share of the market.

Research Hypotheses 7: There is a statistically significant relationship between employee satisfaction and success in commercial organizations.

Conceptual Model

Based on the proposed research hypotheses, the following conceptual model has been developed:

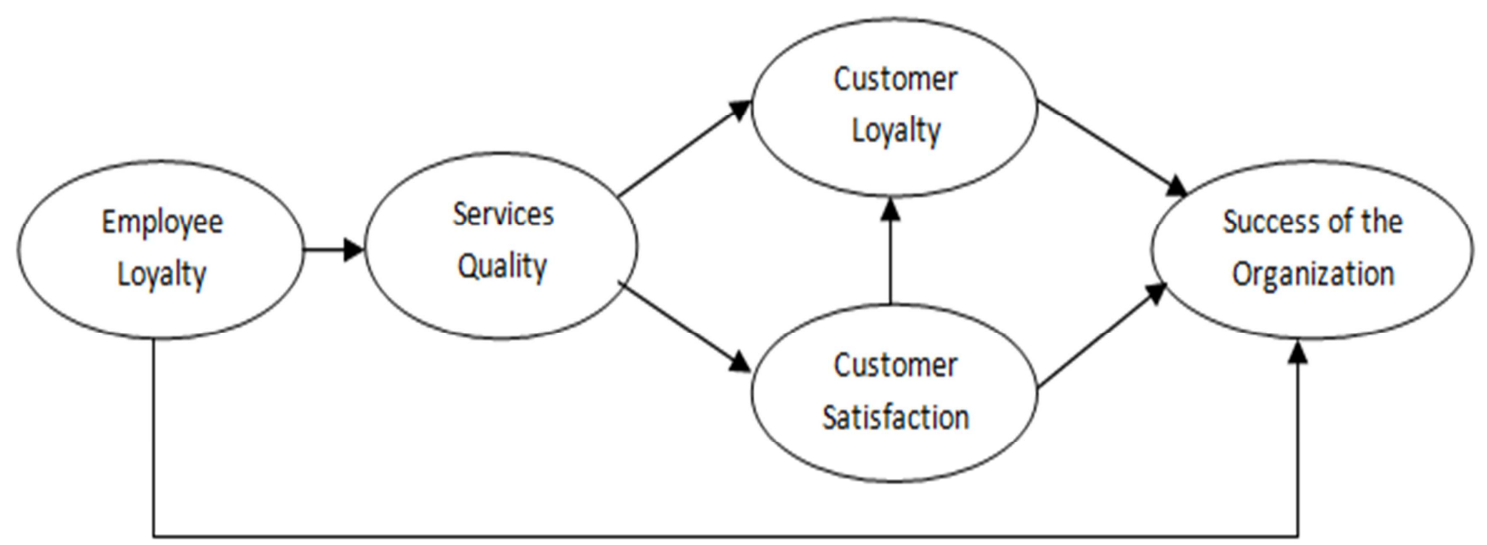

Figure 1. Conceptual Model.

\section{Methodology}

This study set out to investigate the role of employee loyalty in the success of commercial organizations, in the field of heavy construction machineries dealers. This study enjoys a descriptive-survey design.

The sample was comprised of the employees in the heavy equipment dealerships, and the customers who referred to these dealers in the summer 2014. Based on the Cochran formula and Morgan Table, the sample size for the employees was set to be 280 and the same was set for customers. The employees were selected on a stratified random basis, and the customers were selected based on convenience-sampling from the individuals who referred to the dealers of this industry in Iran.

The instruments of data collection were two questionnaires. One was the questionnaire for employees, of which 280 were distributed, and the other was the questionnaire for customers, of which 280 was distributed, as well. The questionnaire for the employees contained a demographic section, which covered question items about age, sex, education, and work experience. It also contained a loyalty section, which covered 4 questions for the investigation of sense of belonging to the organization, the tendency to do more work, high degree of dutifulness, and tendency to remain in the job. These constructs were believed to be able to measure the loyalty to 
organization. The questionnaire for customers contained 20 questions that measured the quality of Services, customer Satisfaction, and customer Loyalty. The quality of services was measured based on the 5 constructs of physical and tangible evidences, reliability, accountability, assuring, and empathy via 13 questions. Five questions were allocated to customer satisfaction, and two questions were allocated to measuring customer loyalty. These criteria were chosen based on the study by Yee et al (Yee, Yeung, \& EdwinCheng, 2010). Indicators in Employees' and customers' questionnaires have been illustrated in Tables 2 and 3.

The hypotheses were checked through statistical procedures of Pearson Correlation Coefficient and regression, which were performed by SPSS software.

Table 1. Indicators in Employees'Questionnaire.

\begin{tabular}{llll}
\hline Question & Indicator & Variable & Number \\
\hline 1 & Sense of belonging to the organization & Employee Loyalty & 1 \\
2 & Tendency to do more work & Employee Loyalty & 2 \\
3 & High degree of dutifulness & Employee Loyalty & 3 \\
4 & Tendency to remain in the job & Employee Loyalty & 4 \\
\hline
\end{tabular}

Table 2. Indicators in Customers' Questionnaire.

\begin{tabular}{|c|c|c|c|c|}
\hline Question & Indicator & Criterion & Variable & Number \\
\hline 1 & Modern Equipment & Physical and Tangible Evidences & Quality of Services & 1 \\
\hline 2 & Proper outfit of employees & Physical and Tangible Evidences & Quality of Services & 2 \\
\hline 3 & Doing the promised services and keeping to the deadline & Physical and Tangible Evidences & Quality of Services & 3 \\
\hline 4 & Showing interest in solving customers' problems & Physical and Tangible Evidences & Quality of Services & 4 \\
\hline 5 & Providing reports with minimum errors & Physical and Tangible Evidences & Quality of Services & 5 \\
\hline 6 & Fulfilling guaranty commitments & Accountability & Quality of Services & 6 \\
\hline 7 & Employees offer the services with no delay & Accountability & Quality of Services & 7 \\
\hline 8 & Employees constantly show interest in helping the customers & Accountability & Quality of Services & 8 \\
\hline 9 & Courtesy and Modesty & Assuring & Quality of Services & 9 \\
\hline 10 & Ample knowledge and expertise & Assuring & Quality of Services & 10 \\
\hline 11 & Employees offer individual attention to customers & Empathy & Quality of Services & 11 \\
\hline 12 & Employees understand the needs of the customers & Empathy & Quality of Services & 12 \\
\hline 13 & Employees consider what is at clients' best interest & Empathy & Quality of Services & 13 \\
\hline 14 & Price & - & Customer Satisfaction & 14 \\
\hline 15 & Information Services & - & Customer Satisfaction & 15 \\
\hline 16 & Customer Services in the Deals & - & Customer Satisfaction & 16 \\
\hline 17 & Positive Verbal Advertisement & - & Customer Satisfaction & 17 \\
\hline 18 & Handling dissatisfactions & - & Customer Satisfaction & 18 \\
\hline 19 & Top Purchase Priority & - & Customer Loyalty & 19 \\
\hline 20 & Recommending to others and encouraging other to purchase & - & Customer Loyalty & 20 \\
\hline
\end{tabular}

In order to check the validity of the questionnaires, necessary adjustments were made. In order to check the reliability of the questionnaires, a pilot sample of 30 employees and 30 customers were formed, and the respective questionnaires were administered to them. The Cronbach's Alpha analysis reported the alpha of 0.84 for the employees' questionnaire, and the alpha of 0.89 for customers' questionnaire. These indicated that both questionnaires enjoyed ample levels of internal consistency. After the functionality of the questionnaires was checked out, 28 dealers of heavy construction machineries were selected on a random basis. In each dealer, 10 employees were selected on a random basis, and the questionnaire was administered to them. Besides, 10 conveniently available customers were selected and asked to fill in the questionnaire.

\section{Results}

Of the 280 employees in heavy equipment dealerships, 162 were male and 118 were female. $42.9 \%$ of the sample aged between 31 and 35, which were most populated age group, and least populated age group was those over 40 with only $2.1 \%$. The university degree with the highest frequency was bachelor's degree, held by 179 (63.9\%) of the employees. It should also be reported that approximately 75 percent of the employees had at least 5 years of experience. These data indicate that the proportion of men and women in the sample was almost equal. Besides, the majority of the participants were educated employees with enough work experience in their business. Hence, it could be argued that the sample had sufficient understanding and knowledge to answer the surveyed questions. The following table illustrates the demographic data of the employees.

Table 3. Demographic data of the employees.

\begin{tabular}{lll}
\hline Percentile & Frequency & \\
\hline $11 / 4$ & 32 & Age between 20 and 25 \\
$42 / 9$ & 120 & Age between 26 and 30 \\
30 & 84 & Age between 31 and 35 \\
$13 / 6$ & 38 & Age between 36 and 40 \\
$2 / 1$ & 6 & Older than 40 \\
9.6 & 27 & Undergraduate Diploma \\
63.9 & 179 & Bachelor's Degree \\
17.1 & 48 & Master's Degree \\
3.6 & 10 & Doctorate \& post-Doctorate \\
5.7 & 16 & N/A \\
25.7 & 72 & Work Experience less than 5 Years \\
38.9 & 109 & Work Experience between 6 and 10 years \\
\hline
\end{tabular}




\begin{tabular}{lll}
\hline Percentile & Frequency & \\
\hline 21.8 & 61 & Work Experience between 11 and 15 years \\
7.1 & 20 & Work Experience more than 15 Years \\
6.4 & 18 & N/A \\
\hline
\end{tabular}

In order to check the hypothesis, the researchers had to check the normality of distribution and make sure that $\mathrm{K}$ was not significant in Kolmogorov- Smirnov test. Then, the researchers were required to depict correlations between the variables so that regression could be administered. The following table illustrates the correlations between the variables. Hence, regression could be administered.

Table 4. Correlations between the variables.

\begin{tabular}{lllllll}
\hline Hypothesis 7 & Hypothesis 6 & Hypothesis 5 & Hypothesis 4 & Hypothesis 3 & Hypothesis 2 & Hypothesis 1 \\
\hline 0.12 & 0.524 & 0.77 & 0.567 & 0.427 & 0.545 & 0.124 \\
\hline
\end{tabular}

Finally, Regression was conducted for each of the seven hypotheses, and through regression, all the seven hypotheses

were accepted. Table 5 illustrates Regression results.

Table 5. Regression results.

\begin{tabular}{llllll}
\hline P-Value & T & Standardized Coefficient & Std. Error & Regression Coefficient & Indicator \\
\hline 0.000 & 15.27 & - & 2.32 & 35.5 & Constant \\
0.04 & 2.06 & 0.124 & 0.174 & 0.36 & Employee Loyalty \\
0.000 & 4.65 & - & 1 & 4.65 & Constant \\
0.000 & 10.68 & 0.545 & 0.025 & 0.263 & Quality of Services \\
0.000 & 5.58 & & 0.454 & 2.53 & Constant \\
0.000 & 7.79 & 0.427 & 0.011 & 0.087 & 2 \\
0.000 & 7.39 & - & 0.324 & 2.39 & Quality of Services \\
0.000 & 11.4 & 0.567 & 0.02 & 0.24 & Constant \\
0.000 & 9.97 & - & 1 & 6.05 & Quality of Services \\
0.000 & 20.5 & 0.779 & 0.039 & 0.8 & Constant \\
0.000 & 4.65 & - & 0.775 & 10.58 & Quality of Services \\
0.000 & 10.22 & 0.524 & 0.126 & 1.29 & Constant \\
0.000 & 13.98 & - & 1.15 & 16.11 & Hypothesis \\
0.046 & 2.01 & 0.12 & 0.086 & 0.173 & Hypothesis \\
\hline
\end{tabular}

\section{Discussion}

In this study, the researchers investigated the impact of employees' loyalty on the success of commercial organizations in the field of heavy construction machineries dealers in Iran. The study reported that employee loyalty has a strong impact in the quality of the services they offer to their employees, and likewise, the quality of services has $\mathrm{s}$ strong impact on the satisfaction and loyalty of the customers This has strong effect on the financial and non-financial success of organizations. In other words, the loyalty of employees could acts as a predictor variable to prognosticate the success of organizations. That is to say the more loyal the employees are, the more hope there will be for the success of organizations.

The results of this study are consistent with the result of the earlier studies. In the study by Daboeian, it was highlighted that employee loyalty was positively correlated with the quality of services, and likewise, the quality of services was positively correlated with customer loyalty in services sector (Daboeian \& Gharechi, 2012). These results are highly aligned with the findings of this study. Besides, the results of the study by Yee et al. (2010), in Hong Kong, revealed that employee loyalty could strongly affect the profitability of organizations. In the study by Jung and Yoon, it was asserted that employee satisfaction was strongly positively correlated with the loyalty and satisfaction of the customers (Jung \& Yoon, 2013). Similar results were also obtained in a Guillon and Cezanne's (2014) study on the impact of employee loyalty on the success of organizations.

\section{Conclusion}

The results of this study highlighted that the loyalty of employees, through the quality of services that they offer and the direct and indirect connection that they have with the customers, has a strong positive impact on the loyalty and satisfaction of the customers. Likewise, having loyal and satisfied customers is the success which commercial organizations are in pursuit of. Hence, commercial organizations must endeavor to absorb loyal employees and increase their organizational commitment. Given the abovementioned discussions and the results raised in this study, the researchers would like to propose the following suggestions:

- Evaluation of the employees, and holding on-the-job training workshops based on the results

- Implementing a rewarding system based on qualifications

- Implementing a suited-time promotion system

- Holding briefing sessions for employees to make them aware of the situation of the company, and informing them of the necessity of hard work and collaboration to promote the quality of the services

- Promoting employees' awareness regarding the importance of respecting the customers

- Promoting the welfare state of the employees 


\section{Acknowledgement}

Hereby, the authors would like to express their gratitude to each and every person who made contributions to this project. Besides, the authors are grateful to all the companies and firms who offered their generous collaboration in the course of conducting this study.

\section{References}

[1] Adler, P. A., \& Adler, P. (1988). Intense loyalty in organizations: A case study of college athletics. Administrative Science Quarterly, 33, 401-17.

[2] Boltanski, L., \& Chiapello, E. (2001). Le nouvel esprit du capitalisme. Revue Francaise de Sociology , 42 (1), 171-176.

[3] Daboeian, M., \& Gharechi, M. (2012). Employee Loyalty Interacy with Customer Loyalty. Modern Marketing Research (3), 27-46.

[4] Dadkhah, M. R. (2010). Customer Orientation. Tehran, Iran: Shahr Ashoob. [In Persian]

[5] Davidhizar, R., \& Shearer, R. (1998). Rewarding with dignity. Hospital materiel management quarterly, 20 (2), 84-89.

[6] Graham, B. W. (1996). The business argument for flexibility. HR Magazine , 41 (5), 104.

[7] Gronholdt, L., \& Martensen, A. (2001). Linking Employee Loyalty, Customer Loyalty and Profitability. Proceedings of the 6th World Congress for Total Quality Management, (pp. 332-339). Saint Petersburg.

[8] Guillon, O., \& Cezanne, C. (2014). Employee loyalty and organizational performance:a critical survey. Journal of Organizational Change Management , 27 (5), 839-850.

[9] Guzman, M., Rodriguez, B., \& Manautou, P. (n.d.). The Link between Customer Satisfaction and.

[10] Heskett, J. L., Jones, T. O., Loveman, G. W., Earl Sasser, W., \& Schlesinger, L. A. (1994). Putting the Service-Profit Chain to Work. Harvard Business Review, 72 (2), 164-174.
[11] Ineson, E. M., Benke, E., \& Laszlo, J. (2013). Employee loyalty in Hungarian hotels. International Journal of Hospitality Management, 32, 31-39.

[12] Jung, H. S., \& Yoon, H. H. (2013). The effescts of employee satisfaction on customers satisfaction and Loyalty in a family resturant. International Journal of Hospitality Management, $34,1-8$.

[13] Kaplan, R. S., \& Norton, D. P. (2008). Strategy- Focused Organization: how balanced scorecard companies thrive in the environment. (P. Bakhtiari, Trans.) Tehran, Iran: Industrial Management Organization. [In persian]

[14] Kavoosi, M. R., \& Saghaee, A. (2010). Methods for Measuring Customer Satisfaction. Tehran, Iran: Ame. [In Persian]

[15] Najafbagy, R. (2010). Change Management: A Glance at Iran Public Administration. Tehran, Iran: Science and Research Branch, Islamic Azad University. [In Persian]

[16] Pourezat, A. A., Ehsanimoghadam, N., Yazdani, H. R., \& Faez, K. (2013). Comparative Analyze of the Impact of Several Dimensions of Organizational Justice on Organizational Climate and Organizational loyalty: (A Research on an IT Based Organization). Public Administration Journal , 5 (13), 65-88. [In persian]

[17] Robbins, S. P. (2012). Organiational Behavior. (A. Parsayan, \& M. A'arabi, Trans.) Tehran, Iran: Cultural Research Office. [In Persian]

[18] Saboori, S. (2014, July 6). Retrieved from http://www.managementportal.ir/2607. [In Persian]

[19] Spinelli, M. A., \& Canavos, G. C. (2000). Investigating the Relationhip between Employee Satisfaction and Guest Satisfaction. Cornell Hotel and Resturant Administration Quarterly, 41 (6), 29-33.

[20] Yee, R. W., Yeung, A. C., \& EdwinCheng, T. C. (2010). An empirical study of employee loyalty, servic equality and firm performance in the service industry. International Journal of Production Economics, Elsevier. , 124, 109-120. 